\title{
Intermediate and definitive hosts of Schistosoma mansoni in Corrientes province, Argentina
}

\author{
C Edgardo Borda ${ }^{+}$, María JF Rea \\ Centro Nacional de Parasitología y Enfermedades Tropicales, Facultad de Medicina, Universidad Nacional \\ del Nordeste, Santa Fé 1432, 3400 Corrientes, Argentina
}

Corrientes province is located in the humid subtropical region of Argentina northeast on the left riverbank of Paraná River in the border with the South of Brazil. This is a region without schistosomiasis but planorbid and rodents that would serve as host of the life cycle of Schistosoma mansoni inhabit here. The objective of this work is to know the role of rodent as definitive host of schistosomiasis.

Biomphalaria tenagophila (4 to $8 \mathrm{~mm}$ Ø) from Maloyas, exposed each to 10 miracidia of $\mathrm{SJ}_{2}$ strain of S. mansoni natives from Brazil were susceptible (5\%). The degree of compatibility was Class II of Frandsen. Five wild rodents captured in the same ecological niche were exposed transcutaneously to infection with 40 cercariae for animal: two Olygoryzomys flavescens, two Holochilus braziliensis, and one Scapteromys tuncidus. Only one H. braziliensis eliminated eggs in feces. Prepatent period was of 83 days. With these feces, two of six (33.3\%) B. tenagophila from Maloyas were infected with miracidium.

It was demonstrated, in an area free of schistosomiasis, that life cycle S. mansoni is closed with planorbid and rodents that live in the same ecological niche.

Key words: Schistosoma mansoni - hosts - Argentina

The southern limits of the geographical distribution of schistosomiasis in Brazil are the states of Paraná, Santa Catarina, and Rio Grande do Sul border the Argentina (Graeff-Texeira et al. 1999). Nevertheless, planorbid snails Biomphalaria straminea and $B$. tenagophila exist in that extensive region irrigated by Paraná and Uruguay River basins. (WHO 1985). Rodents of aquatic habits as Nectomys squamipes and Holochilus braziliensis frequently were found naturally infected with Schistosoma mansoni in areas of high prevalence from Brazil. These mammals would complete a secondary role in the transmission of the disease ( Borda 1972, Kawazoe 1980).

Samples of B. tenagophila from left bank of Paraná River in Corrientes province were infected with the $\mathrm{SJ}_{2}$ strain of S. mansoni and degree of compatibility between the parasite and the snail were compatible with Class II (Borda et al. 2000) using Frandsen method (Frandsen 1979 a,b). These snails also shares the aquatic habitat with several species of rodents among those $\mathrm{H}$. braziliensis (Ringuelet 1977).

As we demonstrated that B. tenagophila maintain the biological cycle of parasite under experimental conditions (snail-hamster-snail) this survey had as objective to know the role of rodent as definitive host. This knowledge has epidemiological importance related with surveil-

Financial support: Secretaría General de Ciencia y Técnica, Universidad Nacional del Nordeste, Corrientes, Argentina ${ }^{+}$Corresponding author: cborda@med.unne.edu.ar / cenpetrop@ hotmail.com

Recived 25 May 2006

Accepted 26 June 2006 lance for the potential for schistosomiasis to expand over a greater geographical area.

Corrientes province is located in the humid subtropical region of Argentine northeast $\left(27^{\circ} 50^{\prime} \mathrm{N}\right.$ and $\left.52^{\circ} 50^{\prime} \mathrm{W}\right)$. Maloyas swamp is expanded in the northwest area of the province between Empedrado and Riachuelo tributaries of the Paraná River (Figure).

Snails identified as B. tenagophila were collected from those habitats some years ago with techniques detailed in a previous work (Borda \& Rea 1997). The snails were exposed and infected with $S$. mansoni miracidia. Descendants of infected snails formed colonies of $B$. tenagophila susceptible and they were used for the maintenance $\mathrm{SJ}_{2}$ strain of $S$. mansoni. The $\mathrm{SJ}_{2}$ strain was isolated from $B$. tenagophila infected naturally in São José dos Campos, São Paulo, Brazil (Paraense \& Correa 1989)

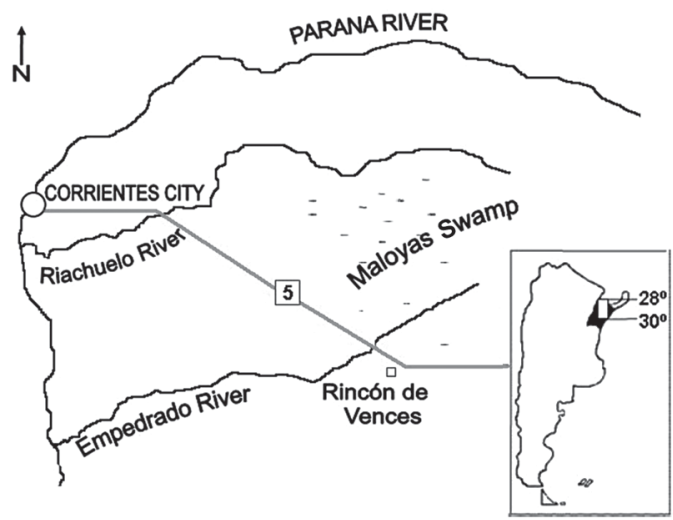

Situation of ecological niche of Biomphalaria tenagophila and Holochilus braziliensis in Maloyas swamp, Corrientes Province, Argentina. 
The capture of rodents began in February 2005. The animals were captured alive by means of traps with ceboo formed by cheese, rice, porridge, and sausage. This way, five wild rodents were captured and identified: two Olygoryzomys flavescens, one Scapteromys tuncidus and two $H$. braziliensis. For the rodents infection each one were exposed transcutaneouly with 40 cercariae within the glass with deschlorinated tap water during $50 \mathrm{~min}$. Cercariae were obtained from seven B. tenagophila sympatric. From 45 days after the exposition, the infection was demonstrated observing the eggs eliminated with the mice feces with the thick smear technique (Borda \& Pellegrino 1971). When the elimination of S. mansoni eggs was proven, the miracidia were concentrated (Chaia 1956) and their number was determined according to the technique of Paraense and Correa (1989).

Six juvenile specimens (4-8 $\mathrm{mm}$ in shell diameter) of $B$. tenagophila from Maloyas were exposed each to 10 miracidia within the glass with deschlorinated tap water during $6 \mathrm{~h}$ under the artificial light at temperature of $28-30^{\circ} \mathrm{C}$.

In three species of rodents, two $O$. flavescens, one $S$. tuncidus, and two $H$. braziliensis, was verified that all the cercariae contained in the watery suspension penetrated in the body of the animals. O. flavescens, $S$. tuncidus, and one sample of $H$. braziliensis died before the time fixed to verify if the schistosomas endogenous phase was completed, with the observation of eggs in feces. In the only $H$. braziliensis survivor, the parasite development was demonstrated until the sexual maturity observing the viable eggs eliminated with the feces. The prepatent period was of 83 days and the eggs elimination stayed constant until the animal death. The rodent had died four days after the beginning of eggs elimination in the feces. Two of six (33.3\%) of B. tenagophila from Maloyas were infected with miracidia of those eggs. The snail infectiousness was verified with the shedding of cercariae from 29 th day.

It was demonstrated that planorbid from Maloyas were susceptible and compatible to the trematoda. On the other hand, the only sample of $H$. braziliensis eliminated eggs that closed the life cycle with the sympatric snails.

Numerous small dams have been built in Corrientes for the rice cultivations where two rivers that end in the Uruguay riverbank are originated (Aguapey and Miriñay). Uruguay River is the natural frontier between Argentina and Brazil.

Workers of both nationalities arrive to these places and they settle down precariously in the periphery of urban centres in proximities of superficial waters.

These experimental observations have not great epidemiological importance because only two samples of $B$. tenagophila from Maloyas were susceptible and compatible to $S$. mansoni and a single captured sample of $H$. braziliensis closed the biological cycle. But, probably both complete the epidemiological chain of transmission if the schistosomiasis spread to Argentina northeast, because they have a wide geographical distribution in Brazil and in the Mesopotamia provinces of Argentina (Misiones, Corrientes, and Entre Ríos).

\section{ACKNOWLEDGEMENTS}

To Dr Wladimir Lobato Paraense for Schostosoma mansoni strain, Instituto Oswaldo Cruz, Rio de Janeiro, Brazil. To Dr Julio Contreras for identification of rodents, Museo Argentino de Ciencias Naturales "Bernardino Rivadavia", Buenos Aires, Argentina. To Miguel Blanco for rodents capture, Estación Biológica San Cayetano, Corrientes. To Osvaldo Benitez and Luis Armando Mosqueda, technical personnel of Cenpetrop.

\section{REFERENCES}

Borda CE 1972. Infecção Natural e Experimental de Alguns Roedores pelo Schistosoma mansoni Sambon, 1907, Belo Horizonte, Minas Gerais, Thesis, Instituto de Ciências Biológicas, UFMG, Belo Horizonte, 44 pp.

Borda CE, Pellegrino J 1971. An improved thick-smear for quantitative diagnosis of Schistosoma mansoni infection. Rev Inst Med Trop São Paulo 10: 71-75.

Borda CE, Rea MJF 1997. Susceptibilidad de Biomphalaria tenagophila de las cuencas de los ríos Paraná y Uruguay a Schistosoma mansoni. Rev Panam Salud Pública 1: 167173.

Borda CE, Rea MJF, Benitez O, Mosqueda L 2000. La esquistosomiasis de Manson, riesgo de su propagación al nordeste argentino y el Paraguay. Medicina 60 (Supl. III): EP 37.

Chaia G 1956. Técnica para concentração de miracídios. Rev Brasil Malariol Doenç Trop 8: 355-357.

Frandsen F 1979a. Studies of the relationship between Schistosoma and their intermediate host. The genus Bulinus and Schistosoma haematobium from Egypt. J Helmintol 53: 15-29.

Frandsen F 1979b. Discussion of the relationships between Schistosoma and their intermediate host assessment of the degree of host-parasite compatibility and evalluation of Schistosoma taxonomy. Z Parasitenk 58: 275-296.

Graeff-Teixeira C, Anjos CB, Oliveira VC, Belloso CFP, Fonseca BS, Valar C 1999. Identification of transmission focus Schistosoma mansoni in the southermost brazilian state, Rio Grande do Sul. Mem Inst Oswaldo Cruz 94: 9-10.

Kawazoe U 1980. Sobre o Comportamento de Alguns Animais Silvestres na Epidemiología da Esquistossomose mansônica Humana, Thesis, Instituto de Ciências Biomédicas, Universidade Estadual de Campinas, São Paulo, 104 pp.

Paraense WL, Correa L 1989. A potential vector of Schistosoma mansoni in Uruguay. Mem Inst Oswaldo Cruz 84: 281-288.

Ringuelet RA 1977. Fauna de agua dulce de la República Argentina. Mammalia (MASSO, AE) VXLII: 59-68.

WHO 1985. The control of schistosomiasis. WHO Technical Report Series 728: 90-104. 